Kohl: a Journal for Body and Gender Research

Vol. 2, No. 2 (Winter 2016)

\title{
Crossing the Border: \\ Rethinking Failure and Exile in Lebanese Musalsalat
}

Heather Jaber

\begin{abstract}
:
This research examines examines three Lebanese musalsalat, Min Kol Albi (Al-Jadeed), Ajyal (MTV), and Ichk Al Nisaa (LBCl), and their portrayal of characters with nonnormative sexualities living in Lebanon. Through the failure and subsequent exile of each character, a commentary on nation and its "constitutive outsiders" (Mikdashi, 2014) can be found. In each character's crossing of the Lebanese border, the negative affects of shame, loss, and failure offer an escape from the "here and now." Through exile, these characters are able to offer alternative ways of thinking about the dominant social structures we inhabit. If we think of failure and loss not as a "refusal of politics" but a "politics of refusal," (Love, 2009) these portrayals offer potential in their capacity to cause a rupture in dominant systems of logic (Halberstam, 2011).
\end{abstract}


"The meaning of modernist transgression—of crossing the line-depends to a great extent on which way you are headed: it is one thing to light out for the Territory and quite another thing to live there."

--Heather Love, Feeling Backward: Loss and the Politics of Queer History

In recent years, an increased visibility of fictional characters with nonnormative sexualities have made their way to primetime television in Lebanon. Often, these portrayals fall into one of two camps of the outsider: the hypersexualized, flamboyant figure, and the tortured figure living in the proverbial darkness. The former presents as comedic devices on satirical sketch programs, featuring jokes about rape or presenting homosexuals as hypersexualized threats to other male characters and the nation, while the latter is portrayed through melodramatic narratives on musalsalat, serialized dramatic narratives of Arab television (Sakr, 2007). While both kinds of portrayals offer grounds for analysis of discourses on the nation, melodrama's capacity to portray "how things are and how they could or should be" (Williams, 2014 , p. 84) have implications for the notion of nonnormative sexuality and other kinds of national "others." By indicating molar polarities and victims of injustice, melodramatic conventions indicate who or what is worthy of empathy, reflecting not only on the hegemonic social orders, but also on the potential for setting a foundation to critique these systems and to enable collectivities to emerge from these darker spaces of the national imaginary.

The programs, which aired on primetime between the years 2010 and 2014, feature three characters who are grappling with their nonnormative sexualities in a Lebanese context. MTV's Ajyal, or "Generations," offers the story of Tamara, a Lebanese compound resident, and Amelia, a mysterious woman from Canada who exhibits an "unnatural" interest in her. Al-Jadeed's Min Kol Albi, or "With All My Heart," introduces viewers to Samih, a married man grappling with what he exhibits as a "shameful" and "disgusting" preference for men. LBCl's Ichk Al Nisaa, or "Women's Love," presents Nadim, who lives in France but attempts to navigate his sexuality in Lebanon amongst his family. In each of these recent primetime drama programs, a character who is regarded as "unnatural" or "deviant" for their romantic preference for the same sex attempts to navigate their sexuality within Lebanese borders while alluding to an assumingly more accepting context beyond them. In some form, each character comes up short against hegemonic masculinities and nationalisms. By each program's end, the characters grappling with their sexuality have chosen to leave Lebanon for a different kind of life abroad.

The discussion of queer existence in these programs and in cultural productions worldwide is then inevitably tied to the notion of the outsider. In Lebanon in particular, outsiders serve as a way to consolidate a national identity that is deeply fragmented by sectarianism, collective amnesia of the civil war, and conflicting narratives of the past. If a key component of the nation is its shared history and symbols, then Lebanon's fragmented national identity is premised upon these tensions. Lebanon is home to various "constitutive outsiders" who solidify a "gendered architecture together as nation" (Mikdashi, 2014 , p. 3). What is more, intersectional identities overlap to "other" them to deeper and deeper degrees. Many are those who leave their homes seeking work or safety. Some are migrant workers seeking employment in a nation that confiscates their passports, drawing not only national borders but borders within the workplace or home. Some are Syrian or Palestinian refugees seeking asylum within the 
Lebanese borders, their bodies often ending up within the borders of makeshift camps. Some of these outsiders are sexual minorities. Although Beirut's status as a "liberal retreat" from the "chaotic" Middle East is widespread, many citizens debate that title (McCormick, 2011). The region now largely maintains the prohibition of homosexuality by law, with penalties ranging across countries from harassment to arrest to death. Lebanon's legal stance on homosexuality is reflected in Article 534 of the Lebanese Penal code, which prohibits "unnatural sexual intercourse" (Makarem, 2011). Men accused of being homosexual are also reportedly still being subjected to arrests and anal examinations despite the Lebanese Order of Physicians banning such practices, which they have labeled as torture ${ }^{1}$ (Rainey, 2014).

It is within this context that these newly visible representations come to contain and create meaning. Contextualizing these representations, then, gives insight into the dominant discourses on sexuality, as well as ways to read these texts against themselves, pushing beyond their dominant meaning. Stuart Hall's concept of low theory, used in Judith Halberstam's ${ }^{2}$ queer readings of popular cultural texts, highlights alternatives to hegemonies and official discourses and breaches the "counterintuitive," giving way to affects we have come to see as negative. "[L]ow theory in popular places" (Halberstam, 2011, p. 21) can then offer alternative modes of knowing or being.

While these portrayals may be viewed as regressive or "negative" for their exiling of these characters coded as homosexual, they may also offer ways out of hegemonic systems of logic. In fact, these representations present the difficulty in differentiating between the two. On the one hand, these characters find themselves on the fringes of their social circles, isolated and suffering, suggesting something essentially ostracizing or deviant in their sexuality. On the other hand, the pain and failure that these characters exhibit may often indicate the reality for queer existence. In the same vein, it is important to consider the nature of these narratives and the manner in which they are rendered visible - the reality on the ground can vary across class, ethnic, religious, and gendered lines. While these portrayals do reflect the notion of "otherness" and marginalization, they cannot be mistaken for the realities of all queer existence across these intersections.

Drawing on Heather Love's (2007) discussion of "useless affects" which have come to be associated with queer existence, reading these portrayals through their darkness and "negativity" can offer productive potential. This departs from liberatory discourses of pride popular in the US and instead allows for a criticism of hegemonic systems of logic. This is not to say that portrayals with affective pulses of joy and pride or other "positive" feelings are solely confined to and manifested in a liberal paradigm; rather, these currents may offer transformative potential when they depart from these systems. Thus, new readings that uncover unconventional affective pulses of empowerment, whether through darkness or light, can offer a critique of the dominant order. Love's call for "a politics forged in the image of exile, of refusal, even of failure" (2007, p. 71) reframes loss as potentially productive rather than the antithesis of progress. Failure, then becomes a way "to poke holes in the toxic positivity of contemporary life" (Halberstam, p. 3) and helps us "understand the contours of the contemporary political situation" (Love, p. 13). Reading

\footnotetext{
${ }^{1}$ While men have been subject to this practice, this is not the case for women, as "unnatural sex" is used to refer to intercourse between men rather than between two women.

2 This book was published under the name "Judith" before the author changed their name to Jack.
} 
these texts through the productive potential of failure, then, may be a more useful way out of these dominant structures.

I would argue that the portrayal of exile from Lebanon provides a mode of "unbeing" or "unbecoming" (Halberstam, p. 97). It is their failure and subsequent exiles that mark their difference from the other characters in the nation. As these characters are not afforded the same happy endings as their counterparts, what are the implications for their melancholic departures? What can failure and exile tell us about dominant systems of thinking? If failure can provide a way to "dismantle the logics of success" (Halberstam, 2009, p. 2) that predominate, what can be learned from these tales of exile? Rather than indicating the characters' "refusal of politics," Love (2009) suggests a "politics of refusal," pointing to the transformative potential of conventionally negative affects. In reading these border-crossing tales of shame, failure, and exile as resistance or rupture from the political present, we can complicate that which seems given and natural and offer a "different relation to knowledge" (Halberstam, p. 19).

\section{Darkness as a strategy}

These particular tales of failure, loss, and exile are told through melodramatic narratives in the Lebanese musalsal. These types of programs are some of the most popular in the region, where television remains the preferred medium of entertainment (Northwestern University of Qatar, 2013). While televised melodrama may be written off by some as a mode of analysis for its use of sensationalist clichés, its status as "the very engine of mass culture" (Williams, 2014, p. 81) means that it can provide insight into a particular historical, political, and social moment. As cultural texts, these portrayals both inform and are informed by circulating values and beliefs in society, providing a landscape of possibility for that which is not wholly formed. Through musalsalat, audiences may critically assess musalsalat "in the context of their everyday lives," (Abu-Lughod, 2005, p.12), indicating that these programs may offer sites of negotiation for audiences.

Melodrama's relationship with the modern persists in contemporary portrayals, offering channels to respond to emerging social change (Hayward 1996 as cited in Mosquera, 2000, p. 66). Melodrama's relationships to mass culture contrasts the way things are with how they could or should be (Williams, 2014 , p. 84). If melodrama is a "dramatic convention in which timely social problems and controversies are addressed" (p. 114), then these tales of exile and border-crossing are told within a historical, social, and political moment that finds Lebanon often regarded as the "capital of the gay Middle East" (McCormick, 2011, p, 74) while maintaining the prohibition of homosexuality by law.

By each show's end, the characters have relinquished their home and their lives in Lebanon. In Ichk Al Nisaa, Nadim plans to return sometime in the future, but is living with his American lover in France for the time being. In Ajyal, Amelia has returned to Canada to be with her lover when things with her neighbor, Tamara, do not work out romantically. In Min Kol Albi, Samih leaves his village and country in an effort to relieve his family of the shame that his secret will surely inflict. Through a melodramatic lens, we can read subjects as worthy of empathy through failures of justice. To present things as moral or just, empathy or sympathy is invoked in the "manifest suffering of an oppressed innocence" (Williams, p. 114). This suffering is exhibited when each character tries to navigate their sexuality within Lebanon. 
Nadim attempts to navigate his sexuality while traveling between Lebanon and France, ultimately confessing his secret to a family friend and horrifying his mother. After she essentially disowns her son, referring to his sexuality as shawedh, or deviance, he tries to enter into a heterosexual relationship to please her and the larger society. When this fails, the viewer finds Nadim distraught in his dark Paris apartment, rocking back and forth in the dark. He goes to a cupboard under the sink as audio flashbacks of his mother saying "I hate you" and "shadh" are replayed. Crying, Nadim takes out two bottles of unknown substances, choosing one and turning it so that the label is clear - mouse poison. Death and suicide are hallmarks in the representation of "gender or sexual deviant," according to Love; "if they manage to survive, it is on such compromised terms that it makes death seem attractive" (Love, 2007, p. 1). Similarly, Samih is driven to contemplate suicide after his wife learns of his secret relationship with the male chauffeur. After his wife taunts him and threatens to expose him to the larger community, he sits on the edge of his bed with a gun in his hand. Ultimately, he chooses to leave his home and family rather than shame them with his secret.

Darkness as an interpretive strategy, according to Halberstam's use of Daphne Brooks (2006), comes from social exclusion and gives way to a commentary of those that experience failure (Halberstam, $p$. 98). Although all of the aforementioned characters eventually leave their families, friends, and homes, it is Samih's exile, in particular, that presents a melancholic rupture that is so familiar to queer history. As Samih packs his things in the middle of the night, the viewer notices a Lebanese flag on his suitcase. He moves slowly, looking around the living room as he walks down the staircase towards the front door. Preparing to leave, he looks around the room and lets his fingers linger on parts of the house, signaling a difficulty in breaking from the here and now. As somber music plays, Samih opens his front door with his suitcase in hand, takes a final glance into his home, and leaves. As he sits in the dark backseat of a moving car, he cries, and a voiceover reads a letter he has written to his father. The letter is an apology and a goodbye, hinting at his dark secret but never naming it. Samih's looking back alludes to what Love calls "the turn backward" (p. 5). In the tale of Sodom and Gomorrah, Lot's wife turns back, defying God's order to venture forth towards the future. "In turning back," writes Love, "toward this lost world she herself is lost: she becomes a monument to destruction, an emblem of eternal regret" (p. 5). If the notion of modernity itself relies on this backwardness, then it relies on figures to represent this backwardness. Queers come to represent the "constitutive others" (Mikdashi, 2014), the "excluded, denigrated, or superseded others," (Love, p. 5).

Samih's disappearance, a break from the here and now into the darkness, can be read as a rupture which critiques a toxic and unaccepting environment. Nadim's suicide attempt in the dark of his kitchen as well as the darkness of his bedroom when he cannot perform sexually exhibit the reality for many queers across time and place, and an indicator of the impact of living in the here and now for many queers. While Halberstam recognizes that "nothing essentially connects gay and lesbian and trans people to these forms of unbeing and unbecoming," (p. 98) feelings of exclusion can foster a relatability that discourses of success and liberation may not. Reading these texts in this way, we depart from a rhetoric of pride and light, which serve to ignore and gloss over the darkness that has inevitably inhabited queer existence. "To feel backward," writes Halberstam of Love's terminology, "is to be able to recognize something in these darker depictions of queer life without needing to redeem them." 
What Love and other scholars like her argue for is the productive or transformative potential of these "useless" affects. She traces the ways that homosexuality comes to signify "the failures and impossibilities of desire itself' (p. 21). While the film Notes on a Scandal received backlash for its "negative" portrayal of homosexuality, says Love (2012), it presented a challenge to the dominant paradigm of progressive politics and womanhood, existing outside of the boundaries of a heterosexual, reproductive normativity. These narratives, then, offer productive potential in their capacity to think beyond the here and now. José Muñoz (2009) highlights the here and now's "totalizing rendering of reality" and instead find, through queerness, "the rejection of a here and now and an insistence on potentiality or concret possibility for another world" (p. 1). These portrayals, then, similarly suggest the here and now as a "prison house" and offer a mode of thinking beyond "the quagmire of the present" ( $p$. 1). Queerness, then, is about looking beyond and outside of the present, to a new landscape of possibility.

\section{Shaming nationalisms}

Attention to the context the programs speak to provides insight into the tension between "homophobic discourse and homosexual existence" (Love, 2009). The relationship with these characters and the "West" uncovers an important theme in melodramatic portrayals of a nation with a history of colonization. In Ichk Al Nisaa, a dramatic scene and cliffhanger suggests that Nadim has a lover in France, as a telephone call between the two finds Nadim telling him, in English: "I miss you too. Babe, don't forget that I love you," followed by dramatic music and lingering shots of the actors closing the episode. The viewer later learns that his lover is Jason, meaning that his love is expressed in English, while he is in France, speaking to an American. In Ajyal, Amelia's declaration of love to Tamara similarly occurs in French: "Tu sais très bien que je t'aime," or, "You know very well that I love you." In the same vein, commentary on class is also uncovered within these narratives, reserving the portrayals of sexual deviance for the upperand middle-class, to be discussed further below.

While one way of reading these texts may point to an association between homosexuality and the West, it also points to "the pressures of morally virtuous and shaming nationalisms" (Georgis, 2013, p. 248) as the reality for queer existence in Lebanon. Joseph Massad's (2007) notion of the Gay International serves as one such way that some of the discourse about sexuality in the region is impacted by imperialism and a postcolonial past. Massad argues that the Gay International - Western gay rights activists with a "universalizing and missionary role" (Amer, 2010) - actually "produces homosexuals, as well as gays and lesbians, where they do not exist" and represses the desires of those who engage in same-sex relationships without wishing to conform to Western sexual epistemology (Massad, 2007, p. 162-3). This suggests that homosexuality as identity is essentially constructed through Western discursivity. While Massad offers an important critique on the repressive effects of universalizing discourses of sexuality and human rights, Diana Georgis points out the repressive effects of the construction of the Gay International itself:

What unpredictable futures and new optics does shame hold for queer Arabs? Shamed locally (when socio-moral codes are publically violated) and globally (for being too gay or not gay enough), queer Arabs are proverbially damned if they do and dammed if they don't. (p. 242) 
As such, it is not a simple case of rejection or acceptance. Perhaps as much as it has been hailed as insightful and seminal, Massad's stance has been critiqued by scholarship (Makarem, 2009; Amer, 2010; Georgis, 2013, Hamdan, 2015) for the lack of agency it affords localized forms of desire, as well as its suggestion of an "origin-to-periphery" (Jacob, 2010) account of sexuality. Still, it is important not to gloss over the context of Lebanon's colonial history, while accounting for contextual specificities. Anne-Marie Fortier (2000) refers to the tendency of many queer theories that discuss diaspora to view them as "movements against any project of fixation, any longing to belong, and often situated outside histories of domination, exploitation, and colonization" (as cited in Shakhsari, 2012). In Hugo Benavides' (2008) reading of melodrama on Latin American telenovelas and narcodramas, he suggests that in contrast to American or British soap operas, they depict a postcolonial legacy, a colonial desire that

expresses a particular kind of longing, even a nostalgia, that is defined both by its characteristic failure (i.e. not being as good as something else in racial and/or cultural terms) and by the constant comparisons to the "other" (i.e. that which is not me/us and that I/we would want to be). (p. 7)

These representations, then, point to the contradictory nature of citizenship in Lebanon. If, in Lebanon, "sexual difference is political difference is sectarian difference is national difference" (Mikdashi, 2015), then any discussion of sexuality cannot be isolated from the tropes of the nation and its historical identity (Aghacy, 2009). Maya Mikdashi (2013) points to the way that sect, gender, and sex are linked in the Lebanese context, noting that there exists almost thirty manifestations of "structural sex-based differentiated citizenship" (p. 351), depending on the intersections of gender, sex, ethnicity, class, and others. Thus, while these portrayals suggest a paradoxical situation for these characters, they present a largely middle-to-upper class subsection of the population. That they are able to imagine a life spatially and temporally beyond their current situation is in and of itself a privilege afforded to those with the economic means to do so. That experiences are compounded by these various intersections suggests quite different experiences across these lines. In these programs, the portrayal of hegemonic nationalisms and masculinities offer commentary on logics of success and an ultimate break from these structures. In queering these portrayals, these "intersections and impasses" surface (Mikdashi, 2013, p. 352).

If ideal masculinity is always unattainable (Halberstam, 2011), these texts indicate this failure. Each character, in some form, exhibits a failed masculinity through their own failure to live up to these ideals. This is the case when Nadim is unable to perform sexually after attempting to enter a relationship with a woman. He sits on the edge of his bed, telling his disappointed girlfriend, "I can't. I'm not able to;" his failure to perform sexually directly precedes his suicide attempt. In Min Kol Albi, when Samih's wife, Lina, finds out that her husband "prefers men," she taunts him, suggesting that his masculinity is in question. She achieves a sort of power over her husband, suggesting that he listen to his wife now. "That's how a man should be," she says, pinching his cheek in front of his father and continuing to taunt him in private.

The notion that in Lebanon "homosexuality is the negation of masculinity" (Merabet, 2014, p. 126) plays out in these programs, highlighting a failure to live up to certain ideals. Through these representations, we can question why "certain ways of being male predominate," (Donaldson, 1993). In melodrama, this contrast is pronounced, indicating that the characters and larger ideologies merit the recognition of a 
"fundamental utopianism" (Williams, 2014, p. 84). Masculinity studies juxtapose dominant masculinities with an unstable, threatened masculinity, suggesting that "threat" and "failure" are ideological tropes used to maintain a hegemonic masculinity (Conway, 2008). Homosexuality, then, appears in conversation with hegemonic masculinities and nationalisms, offering insight into dominant modes of thinking. According to Wilson Chacko Jacob, nationalist discourse in the region has historically been connected to what have been termed "male values," such as honor (Jana, p. 220). This contrasts the "useless" feelings of shame exhibited by many of the characters, mainly in the face of these hegemonic nationalisms.

These hegemonic masculinities present as nationalist tropes through several characters on the programs. Samih's ultimate reason for leaving is to avoid bringing shame to his family, especially his father, the beloved village mayor. When his father reads his goodbye letter, he nearly collapses from the shock, suggesting a rocking of the nation itself. He eventually maintains stability and finishes the letter, ultimately crying out for his son. "I love him as he is," says Samih's father, the mayor, although he rewards another character with upper-class mobility through an opportunity for an education while his son must live in exile. These representations are similar to those of contemporary Arab literature, where themes of masculinity have been presented through various tropes. In postwar Lebanon, Samira Aghacy (2009) traces the ways masculinity has been represented as not only reinforced, but also destabilized. The near collapse of Samih's father recalls tropes in Arab literature which favor stability over ambiguity (Aghacy, 2004 , p. 2). Adel, the love interest of Nadim's mother and the ultimate hegemonic masculinity on the program, offers the only manner through which Nadim can live in Lebanon. Adel's status as a politician fighting corruption in Lebanon and his near assassination and escape from martyrdom serve to establish a stable masculinity, which contrasts Nadim's ambiguity. It is through Adel that we learn of Nadim's sexuality; it brings it to the forefront and confronts him with his choices for the here and now. As I will discuss further, Nadim chooses neither.

In Ajyal, Amelia's sexuality is also related to man's failure, predicated by a failed heterosexuality and evident when she says, "I started loving women when I started hating all men." When Amelia first arrives to the compound, she is shrouded in mystery, much to the interest of Tamara, who loves all things "foreign." Amelia's comments about Lebanon highlight the political and social terrain of the nation, apparent when she calls them "cute" for their disregard of their respective religions. "How do they say there is sectarianism in the country?" she asks a group of people who leave her question unanswered. Farah, a widowed mother and compound resident, is offered as a juxtaposition. She represents the quintessential view of women in the Arab region as "bastions of traditional values" (Aghacy, p. 2), remaining celibate after the death of her husband and struggling with her own desires following the advances of a new love interest. Her relationship to her husband in death is made all the more iconic by his status as a soldier, and therefore, a martyr. Through this juxtaposition of Amelia and Farah, I suggest a reading that critiques the traditional tropes of the nation. Just as Halberstam suggests that the transgender characters of 50 First Dates "represent the dangers of life outside of the nuclear family," Amelia also offers, within the dominant reading, a cautionary strain on the nation itself. If melodrama is a "dramatic convention in which timely social problems and controversies are addressed" (Williams, 2014, p. 114), Amelia and Farah present as symbols of the nation, steeped in its patriarchal tradition. While Amelia moves beyond this here and now, Farah remains and grieves the death of her child. This alludes to the nation as fraught, pointing to the toxicity of its systems of logic. 


\section{Illegibility as a strategy}

Despite the commentary of the nation and its outsiders, a look at these locally-produced musalsalat shows no superficial traces of a deeply fragmented society. Characters on locally-produced Lebanese musalsalat are largely Lebanese rather than Muslim, Christian, or Druze; they stand in for the nation rather than one of Lebanon's 18 sects. In reality, Lebanese national citizens carry identification cards that mark their religion and sect, providing a way for the state to render them legible. Halberstam refers to James C. Scott's work on the seemingly natural social and political practices of the state, which serve to impose "methods of standardization and uniformity" (Halberstam, p. 9) on its inhabitants. As such, the state has become "the enemy of 'people who move around," (Scott, 1999 as cited in Halberstam, 2011, p. 9) and has served to manipulate certain people "when they become legible and visible to the state (undocumented workers, visible queers, racialized minorities)" (p. 10).

This commentary on visibility is especially apparent in a scene where Samih's wife, Lina, discovers his dark secret. She walks around to the back of the house to find her husband and comes to the pool house. She sees the family chauffeur holding out his hand and pulling Samih into a dark area of the room which is out of frame. Although their apparently intimate moment is obstructed from camera view, Samih's hand on the chauffeur's shoulder and physical proximity allude to a kiss. When Samih realizes he has been seen, the chauffeur seems to disappear into the background, and quite literally into the dark. The implications for class in this scene are stark-the chauffeur to the wealthy family never appears before or after this scene, fading from the screen and from the world of the characters. A near invisibility of nonupper class homosexuals on this program and others highlights the manner in which nonnormative sexuality is rendered visible.

Such is the case for the other characters coded as homosexual. Amelia is vacationing in a luxurious Lebanese compound for the summer; Nadim is the son of a wealthy hospital director and flies back and forth between his Paris apartment and Lebanon; Samih is the wealthy son of the town mayor, driving a sports car and accusing his wife of marrying him for his money. Where are the portrayals of the 52 Egyptians arrested during the Queen Boat Raid and tried as quasi-terrorists and national threats? ${ }^{3}$ Where are the 36 men arrested from the Bourj Hammoud cinemas following the appeal to state action on "Inta Hurr" (ironically translating to "You Are Free")?4 What of the 28 arrested at Hammam al-Agha?5 Saleem Haddad (2016) highlights the dilemma of queer Arabs who become hypervisibilized through the state.

\footnotetext{
${ }^{3}$ The Queen Boat raid in Egypt saw the detention of 52 Egyptian men from a gay tourism boat. The men went to prison in the midst of emergency counterterrorism decrees and framing by national police that they were quasiterrorists.

${ }^{4}$ The program aired secret video footage of men engaging in sexual activities and watching pornography in an abandoned cinema, and was broadcast on MTV's tabloid show "Enta Horr" ("You Are Free"). The show's anchor, Joe Maalouf, called on religious clerics and police to put a stop to these activities, expressing his disgust with the mens' actions. Police subsequently raided the cinema, arrested the men for "having unnatural sex," and enforced the "anal test" to determine their guilt (Mandour, 2013).

5 In 2014, 28 people were arrested from a Turkish bathhouse in Beirut and charged with various crimes, including Article 534, the law on "intercourse contrary to nature" (Frangieh, 2014).
} 
...[p]rivacy is a luxury that is only afforded to those who can pay for it. If you have money you can buy yourself a gay identity in Mykonos. If not, then head to a rundown cinema and hope for the best.

In his discussion of security regimes in Brazil and Egypt, Paul Amar (2013) points to sexualized publics in Egypt as important to the state's modernization efforts through the tourism market and economic globalization, but, on the flip side, as "agents of cultural impurity and colonial penetration" (p. 70). As such, economic power plays an important role in the degree to which visibility, therefore state legibility, is allowed. The very citizenship these characters correspond to are those supporting and maintaining dominant economic models. Just as the commercialization of the female body in Lebanon is allowable when state-sponsored through tourism videos (Mikdashi, 2014), the homosexual is allowable as a proponent of the dominant economic model. The 52 Egyptian men arrested were then associated with the perversion of globalization, ignoring the "foreign" men who were found on the boat but ultimately not detained. The portrayals on the drama programs, and especially the chauffer's disappearance into the dark void, highlight the landscape for nonnormative sexuality for the Lebanese. "Who owns queer Arab bodies?" asks Haddad. When do these bodies become visible and legible to the state? In Ajyal, Amelia's sexuality only becomes a point of suspicion and fear when a doctor in the compound suggests her behavior is "unnatural." Drawing on Foucault (1973), medical knowledge becomes a form of discipline, carrying power in the doctor's "gaze." At the point when Amelia's "unnatural" nature becomes evident, the doctor's gaze moves from observer to the gaze "of a doctor supported and justified by an institution, that of a doctor endowed with the power of decision and intervention" (p. 89). Thereafter, compound residents gossip about the danger of her unnatural ways. While she maintains an air of intrigue while illegible, the diagnosis by the doctor categorically visiblizes and renders her not only legible, but something to be contained.

\section{Movement and passivity}

The movement of the characters in these programs may then be seen as a way to achieve illegibility, breaking from the regimes of knowledge and disciplinarity, which would otherwise reproduce hegemonic modes of being. Halberstam, recognizing that although sexual minorities and former slaves cannot be reduced to the same experiences, offers Saidiya Hartman's commentary on the productive potential of movement:

As a practice, moving about accumulated nothing and it did not effect any reversals of power but indefatigably held onto the unrealizable —-being free-by temporarily eluding the constraints of order...Like stealing away, it was more symbolically redolent than materially transformative" (128).

Movement, then, departs from other more explicit and romanticized forms of resistance, offering passivity as a mode of defiance against the dominant order. Rather than offering a narrative of success, pride, or achievement, freedom may be achieved through passivity and illegibility, recognizing that there is a "not yet realized social order" (Halberstam, p. 130). As such, imagining freedom outside of the constraints of dominant logics of success may mean symbolically moving beyond these structures of domination. Across these texts, a discomfort with ambiguity and instability draws on tropes from other postwar fiction. Amelia's arrival to Tamara's life brings mayhem to the compound in the way of infidelity, disease, and 
even death. Upon her departure from the compound, a relative calm ensues, reflecting the way her ambiguous nature disrupted the social fabric. Samih's father is almost destabilized by Samih's secret, portraying the fraught nation as it comes to head with these tensions.

The logics of success in these programs are then presented through linear narratives of kinship (Halbertstam, 2011) and favor stability rather than ambiguity. In a conversation Nadim is listening to, his mother says to her daughter, "Every woman needs a man, and every man needs a woman. That is human nature. Except in exceptional circumstances." Dramatic music plays and the shot pans to Nadim's reaction as he realizes she is talking about him. "No one is able to live by themselves without feeling emotionally empty or something is missing. Nothing else will fulfill that or replace it." The dominant logic, then, requires that a man and a woman must find one another to seek fulfilment, leaving the losers at the fringes of this social fabric. Nadim's seating place between his mother and sister highlights the nature of these dominant logics, spoken between their propagators at the expense of the losers it isolates. It is to "history's losers" that Halberstam dedicates her book, The Queer Art of Failure, as they are armed with the tools needed to critique the toxic system.

Logics of success like the above have the ability to create cohesion through an imagined collectivity. Drawing on Benedict Anderson, Diana Georgis highlights how tradition is manifest in an imagined community and "instrumentalized in the fight against imperialism and globalization" (p. 236). Svetlana Boym (2012) also draws on Anderson in her work on the notion of home and the nation, pointing to the limitations of his anthropological rather than ideological notion of the nation. By resisting "a coherent narrative of identity," (p. 242) Boym suggests that many modernist writers tell the important stories of the exiles and misfits who offer alternative narratives departing from dominant history:

Instead of curing alienation-which is what the imagined community of the nation proposesthey use alienation itself as a personal antibiotic against the ancestral disease of home in order to reimagine it, offering us new ways of thinking about home, politics, and culture. (p. 242)

Through these programs, then, the individual's removal from the collective allows for a resistance to the dominant modes of being. Through this separation or rupture, "unbecoming" serves as a way to step outside of the array of choices offered, to create new paths, to be rendered illegible. Nadim's narrative in particular offers insight into this "politics of refusal" of dominant logics of success. In one scene, Nadim and Adel discuss his options for remaining in Lebanon.

Adel: Come back and live here, in your country. You know very well there are a lot of people like you in this country. At all levels and careers. Some are unveiled/open (makshouf) and some are hidden (mkhabba). And it doesn't make a difference to them.

Nadim: And which kind should I be?

Adel: I want you to be you. I want you to be yourself.

Nadim: I understand from you that you are telling me, in another way, to hide.

Adel: Not at all. Not at all Nadim. I'm asking you not to reveal information that has nothing to do with others. We're all surviving and we all have secrets.

Within Lebanon, as communicated through Adel, Nadim is presented with two options: in or out. Here, the trope of the closet is recalled, drawing on the debate between scholars who take an identity-based 
stance, as per Eve Sedgwick (1990), and those who argue for the performative nature of gender and sexuality, as per Judith Butler (2004). While being "out" of the proverbial closet suggests a binary identity based on one's relationship to the closet, these programs present a critique of this rhetoric of "in" or "out." For Arabs who occupy places of shame both globally and locally (Georgis, 2013), this indicates an important break from binary categorization. Here, we find a break from the here and now and a move towards a new landscape of possibility for queerness. Illegibility as a strategy then offers productive potential for the queer Arab. Halberstam suggests that popular cultural texts may present ruptures from a "definitive past" and a "prescriptive future" (p. 82). Symbolically, as these characters move away spatially, they also move to another time. The national border symbolizes this rupture, offering an imaginary escape from the heteronormative structures in place. Various queer readings of popular cultural texts also highlight this reach towards "somewhere else." In Alexander Doty's (2002) reading of "The Wizard of Oz," he suggests that Dorothy's journey to $\mathrm{Oz}$ is a journey of sexual discovery. Going "over the rainbow" quite literally signals her sexual awakening. In reaching beyond the figurative rainbow - in this case, the border - Samih, Nadim, and Amelia break from the here and now.

\section{Melodrama and the nation: Self-exile or forced exile?}

While all characters leave Lebanon by the end of the program, the distinction between a choice of exile and a forced exile has implications for a reading of their departure. Hugo Benavides' (2008) account of telenovelas and narco-dramas in Latin America highlights the significance of melodramatic identification and a commentary on the nation. He takes the example of real-life figure Juan Soldado, a Mexican soldier who was killed trying to escape the Mexican border in 1938. The man was accused of raping and killing a young girl, although many accounts deny his guilt while describing his "gruesome death" just before reaching the border.

Symbolic renderings of this character's failure to cross the border in search of freedom and an opportunity to prove his innocence provide a form of "melodramatic identification" for migrants who seek out "the allure of the north" (Benavides, p. 137) for socioeconomic or political means. Although, unlike many of these migrants, his attempted border-crossing was not voluntary, Juan Soldado becomes a metaphor for those who have experienced systemic injustice and failure. The contrast between voluntary movement or forced movement then serves to draw greater attention to the "unfair and unjust structure that forces Mexicans and other Latin Americans to abandon their countries and homes to seek a future in the racially ambivalent United States" (Benavides, p. 138). In the same vein, the exile of the characters in Lebanese musalsalat may allow viewers to identify with these losses and harness their productive potential.

In a discussion of exile in modernist queer texts, Heather Love draws on the ambiguity between self- and forced exile. Self-exile, according to Love, may take on a sort of "heroic sacrifice" (p. 54) that is not afforded by forced exile. Forced exile, though, is not easily differentiated from self-exile, often the result of modern-day afflictions of marginalization and migration. In her reading of The Renaissance by nineteenth-century novelist Walter Pater, Love suggests that Boticelli's sad angels tell a melancholic tale of queerness. Theirs is "a spatial and a temporal displacement" (p. 64), and a narrative of loss and exile follows their alienation and exclusion from dominant paradigms and structures. At odds between "the home" and "the closet," their wistfulness, sadness, and melancholy reminds readers that they do not 
inhabit this space by choice. In the same vein, these characters' feelings of shame and even disgust remind us of the reality for many who are left out as history's losers. As such, they are not useless affects, but affects that foster collectivities instead.

While the characters in these musalsalat technically leave on their own accord, theirs may also be thought of as a case of forced exile. "One ends up there not by choice," writes Love, "but rather by refusing to choose" (p. 64). As such, they escape linear narratives of kinship, existing outside of space but also time. In this way, forced exile becomes a way to sidestep the binaries offered to these characters. Rather than "in" or "out," they suggest something else altogether. The exact form of this choice is not evident, but that is perhaps the point. Choice through refusal indicates an ambiguity that is potentially transformative in nature.

Perhaps the greatest indicator of this exile's transformative potential is presented in a scene following Amelia's departure. Tamara sits with Maher, a compound resident, who asks her about her relationship with Amelia, prodding for details of its nature. Tamara tells him that Amelia was "a different story" from all the other characters in her life. She wasn't herself, she says - she was a new person with her. Tamara's demarcation between her old self and the person she was with Amelia is significant. With Amelia, she said, she experienced "a beautiful connection, a strange connection." She does not answer Maher's question outright, instead suggesting an ambiguity in her relationship with Amelia. This constitutes the new type of openings that exists when the here and now is traversed.

\section{Conclusion}

In each program, these characters quietly exit the nation, but more symbolically, the logics of success that exist in the current time and place. Their failure and therefore resistance is subtle, but it should not be mistaken as empty. Halberstam describes the queer art of failure as one where the queer "quietly loses, and in losing it imagines other goals for life, for love, for art, and for being," (p. 88). The national borders that these characters symbolically cross then come to represent a break from the here and now, offering a discontinuity which informs the narratives of many queer texts.

Their exits do not point to a utopic discourse of acceptance and assimilation, but offer something more potentially useful and honest in the process. It is important to consider why, in this place and time, there is a heightened visibility of these storylines potentially forging a "negative freedom" through loss (Halberstam, 2014). These portrayals are then significant in their indication of structures of feeling, rather than official changes in discourse, surrounding the discussion of nonnormative sexuality in Lebanon. In doing so, we can begin to trace a historical moment that is taking shape. What these representations do afford is a visibility of the sites of shame and pain, which serve as "a metaphor for becoming out of shame and difficult affect, between two epistemologies, articulating what is yet to have a name or a theory but has an emotional shape" (Georgis, 2013, p. 248).

Still, while these characters are depicted as bypassing hegemonic binaries, they do not critically interrogate the homonormative systems of logic which pervade. While these portrayals indicate affective pulses that render collectivities possible, they offer narratives of a largely upper-class subsection of 
citizenship. That their only manner of queer becoming occurs through geographic exile may ignore local negotiations, which occur to offer ways out of homonormative binaries. When other classes are portrayed, characters like the chauffeur fade into the darkness, offering other kinds of interpretive strategies. It is these within these moments that the "cracks and fissures" (Gopinath, 2005, p. 153) in linear narratives bring to the surface the contradictions which pervade.

That these characters are relatively new representations interacting with the established hegemonic heteronormative, expressing loss, failure, and rejection means that they form, however embryonic, alternative modes of thought or emerging structures of feeling. Heather Love's call for "a politics forged in the image of exile, of refusal, even of failure" (2007, p. 71) reframes loss as potentially productive rather than the antithesis of progress. While some may view the ultimate exit of all of these characters from the programs and nation as problematic in the dominant discourse of representation, reading against the grain to harness the potential of negativity offers alternative modes of being beyond the choices in our dominant systems of logic. 


\section{References}

Aghacy, S. (2009). Masculine identity in the fiction of the Arab East since 1967. Syracuse, N.Y.: Syracuse University Press.

Amer, S. (2010). Joseph Massad and the alleged violence of human rights. GLQ: A Journal of Lesbian and Gay Studies, 16(4), 649-653.

Benavides, H. (2008). Drugs, thugs, and divas: Telenovelas and narco-dramas in Latin America. Austin: University of Texas Press.

Boym, S. (2012). Estrangement as a lifestyle: Shklovsky and Brodsky. In S. R. Suleiman (Ed.), Exile and creativity: Signposts, travelers, outsiders, backward glances (241-262). Duke University Press.

Butler, J. (2004). Undoing gender. Routledge: New York and London.

Conway, C. (2011). Behold the man: Jesus and Greco-Roman masculinity. New York: Oxford University Press.

Brooks, Daphne. 2006. Bodies in Dissent: Spectacular Performances of Race and Freedom, 18501910. Durham: Duke University Press.

Donaldson, M. (1993). "What is hegemonic masculinity?" Theory and Society, Special Issue, 22(5), 643-657.

Doty, A. (2002). "'My beautiful wickedness:' The Wizard of Oz as lesbian fantasy." In H. Jenkins III, T McPherson, \& J Shattuc (Eds.), Hop on pop: The politics and pleasures of popular culture. (138-157). Duke University Press.

Fortier, A. (2000). Coming home: Intersections of queer memories and diasporic spaces. Paper presented in the "Queer Theory" seminar series of the Institute of Women's Studies, Lancaster University. Retrieved from: http://www.omnilogos.com/2011/05/24/queer-diaspora.

Frangieh, G. (2014). The Hammam al-Agha raid: Collective prosecution in violation of individual rights. The Legal Agenda.

Georgis, D. (2013). Thinking past pride: Queer Arab shame in Bareed Mista3Jil. International Journal of Middle East Studies, 45, 233-251.

Gopinath, G. (2005). Impossible Desires: Queer Diasporas and South Asian Public Cultures. Duke University Press Books.

Haddad, S. (2016). The myth of the queer Arab life. The Daily Beast. Retrieved from http://www.thedailybeast.com/articles/2016/04/02/the-myth-of-the-queer-arab-life.html

Halberstam, J. (2011). The queer art of failure. Durham and London: Duke University Press.

Hamdan, S. (2015). Re-Orienting desire from with/in queer Arab shame: Conceptualizing queer Arab subjectivities through sexual difference theory in a reading of Bareed Mista3jil. Kohl: a Journal for Gender and Body Research, 1(1), 55-69.

Hartman, S. 1997. Scenes of Subjection: Terror, Slavery, and Self-Making in Nineteenth Century America. Oxford: Oxford University Press.

Hayward, S. (1996). Key Concepts in Cinema Studies. New York: Routledge.

Jacob, W. C. (2011). Working Out Egypt: Effendi Masculinity and Subject Formation in Colonial Modernity, 1870-1940. Duke University Press Books.

Jana, K. (2015). Changing heads and hats: Nationalism and modern masculinities in the Ottoman Empire and the Republic of Turkey. In P. D. Andersen \& S. Wendt (Eds.), Masculinities and the nation in the modern world. (217-242). Palgrave Macmillan. 
Love, H. (2009). Feeling backwards: Loss and the politics of queer history. Cambridge: Harvard University Press.

Love, H. (2012). Gay marriage and its others [video]. Retrieved from http://clarke.dickinson.edu/heather-love/

Makarem, G. (2011) "The story of HELEM." Journal of Middle East Women's Studies, 7(3) 98-112.

Massad, J. (2007). Desiring Arabs. Chicago: University of Chicago.

Mikdashi, M. (2013). Queering citizenship, queering Middle East studies, International Journal of Middle East Studies, 45, p. 250-52.

---. (2014). Moral panics, sex panics and the production of a Lebanese nation. Jadaliyya. Retrieved from http://www.jadaliyya.com/pages/index/16570/-moral-panics-sex-panics-and-theproduction-of-a-l

---. (2015). Does The nation-state have a hymen? The state of sexual, national, and gendered regulation in Lebanon [Talk].

Mosquera, J. (2000). Democratic gays, modern gays: The construction of homosexual characters in Spanish films during the transition [Master's thesis].

Muñoz, J. (2009). Cruising utopia: The then and there of a queer futurity. New York: New York University Press.

Najmabadi, A. (2008). "Transing and transpassing across sex-gender walls in Iran." Women's Studies Quarterly, 36(3 \& 4), 23-42. doi:10.1353/wsq.0.0117

Northwestern University in Qatar. (2013). Media Use in the Middle East: An eight-nation survey.

Rainey, V. (2014). "Banned anal exam still being used as homosexuality test." The Daily Star. Retrieved from http://www. dailystar.com.Ib/News/Lebanon-News/2014/Jul-16/264004-bannedanal-exam-still-being-used-as-homosexuality-test.ashx

Sakr, N. (2007). Arab television today. London: I. B. Tauris \& Co. Ltd.

Sedgwick, E. (1990). Epistemology of the closet. University of California Press.

Scott, J. C. (1987). Weapons of the weak: Everyday forms of peasant resistance. New Haven and London: Yale University Press.

Shakhsari, S. (2012). From homoerotics of exile to homopolitics of diaspora: Cyberspace, the War on Terror, and the hypervisible Iranian queer. Journal of Middle East Women's Studies, 8(3), 1440.

Williams, L. (2014). On the wire. USA: Duke University Press. 